\title{
Sınıf Öğretmenlerinin Beden Eğitimi ve Oyun Dersine Yönelik Tutumlarının İncelenmesi*
}

\section{The Investigation of the Attitudes of Classroom Teachers towards Physical Education and Game Lesson}

\begin{tabular}{|c|c|}
\hline \multicolumn{2}{|r|}{ Aylin Tümkaya Yenmiş, Mehmet Gül } \\
\hline Yazar Bilgileri & ÖZ \\
\hline $\begin{array}{l}\text { Aylin Tümkaya Yenmiş } \\
\text { Sinıf Öğretmeni, Cumhuriyet } \\
\text { Üniversitesi Illkokulu, } \\
\text { aylintumkaya@hotmail.com } \\
\text { Mehmet Gül@ } \\
\text { Doç. Dr., Sivas Cumhuriyet } \\
\text { Üniversitesi, Spor Bilimleri, } \\
\text { mehmetgul@cumhuriyet.edu.tr }\end{array}$ & 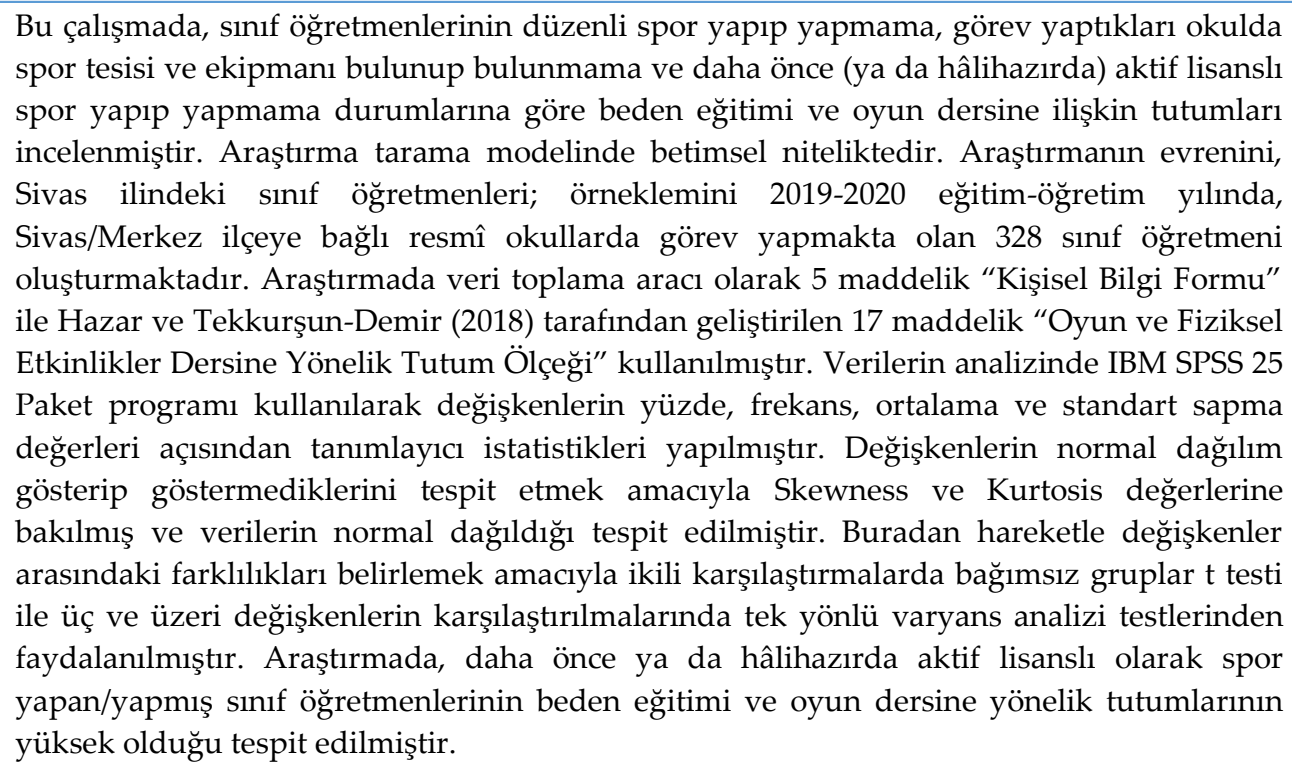 \\
\hline
\end{tabular}

\section{Makale Bilgileri}

Anahtar Kelimeler Sınıf Öğretmeni

Tutum

Beden Eğitimi

Oyun

\section{Keywords}

Classroom Teacher

Attitude

Physical Education

Game

\section{Makale Geçmişi}

Geliş: 21.09.2021

Düzeltme: 10.10 .2021

Kabul: 03.12.2021

\begin{abstract}
In this study, classroom teachers' attitudes towards physical education and game lessons were examined according to whether they do sports regularly, whether there are sports facilities and equipment in the school they work in, and whether they have previously done (or currently) actively licensed sports. The research is descriptive in the scanning model. The universe of the research is the classroom teachers in Sivas; the sample consists of 328 classroom teachers working in public schools in Sivas central district in the 2019-2020 academic year. In the research, a 5-item "Personal Information Form" and a 17-items "Attitude Scale towards Play and Physical Activities Lesson" developed by Hazar and Tekkurşun-Demir (2018) were used as data collection tools. In the analysis of the data, descriptive statistics of the variables in terms of percentage, frequency, mean and standard deviation values were made using IBM SPSS 25 Package program. Skewness and Kurtosis values were examined in order to determine whether the variables showed a normal distribution and it was determined that the data were normally distributed. From this point of view, in order to determine the differences between the variables, independent groups ttest was used in pairwise comparisons and one-way analysis of variance tests were used in the comparison of three or more variables. In the research, it has been determined that the attitudes of the classroom teachers who have previously or currently actively engaged in sports or have done sports, towards physical education and game lessons are high.
\end{abstract}

*Bu çalışma, ikinci yazar danışmanlığında birinci yazar tarafından yürütülen yüksek lisans tezinden üretilmiştir. 


\section{Giriş}

Milletlerin kalkınmasında en önemli unsur olan "eğitim ve öğretim" planlı yürütülmesi gereken geliştirici çalışmalar bütünüdür. Eğitimin amacl; bedenen, ruhen, zihnen, ahlaken ve duygularıyla dengeli ve sağlıklı bir bütün olarak gelişen; özgür, evrensel bir dünya görüşünü benimseyen, bireyin haklarını özümseyen, içinde bulunduğu topluma karşı sorumluluk duyan; yapıcı, yaratıcı ve yenilikçi bireyler yetiştirmektir (Karakoç ve Sezer, 2007).

Eğitim programları; bireylerin akademik anlamda en iyi donanıma erişmesini hedeflemenin yanı sıra, güçlü bir iradeye ve karaktere de sahip olmasını hedefler. Dünyanın her yerinde eğitim, bireylerin içinde yaşadıkları toplumun kültürünü ve değer yargılarını özümsemesini ister. $\mathrm{Bu}$ düşünceden hareketle bireylerin bir bütün olarak eğitilebilmeleri için fiziksel, duyuşsal ve toplumsal gelişimlerine imkân tanıyacak eğitim hedeflerine uygun faaliyetlere de öğretim kadar önem verilmektedir. $\mathrm{Bu}$ faaliyetlerin büyük bir kısmını, beden eğitimi ve oyun dersinde gerçekleştirilebilecek aktiviteler oluşturmaktadır (Kuru, 2003).

DeCorby, Halas, Dixon, Wintrup ve Janzen (2005), motor hareketleri sağlayan becerilerin gelişiminde, fiziksel uygunluğun sağlanmasında, sağlığın devamlılığında beden eğitimi ve oyun dersinin önemi küçümsenemez faydaları bulunduğunu; bunun yanı sıra öğrencilerin toplumsal ve duygusal gelişimini önemli ölçüde desteklediğini ifade etmiştir. Fiziksel aktivite deneyimleri aracılığıyla her öğrencinin büyüme ve gelişimine önemli katkılar sağlayan beden eğitimi ve oyun dersi, eğitim programlarının tamamlayıcı bir parçası olarak modern eğitim anlayışında önemli bir yere sahiptir. Fertlerin hayat boyu psikolojik ve fiziksel açıdan sağlıklı, dinç ve dinamik olabilmesi öğrencilik süresince alacağı eğitimle yakından ilgilidir (Pehlivan, Dönmez ve Yaşat, 2005).

2012 yılında güncellenen müfredatla birlikte ilkokul 1, 2 ve 3. sinıflarda haftada 5; 4. sinifta ise haftada 2 ders saati olarak okutulan oyun ve fiziki etkinlikler dersiyle öğrencilerin oyun ve fiziki etkinlikler yolu ile gerek bedensel gerek zihinsel gerekse duygusal açıdan gelişimleri desteklenerek yaşam becerileri ile insani değerleri gelişmiş bir şekilde bir sonraki eğitim ortamına hazırlanmaları hedeflenmiştir. Oyun ve aktivite aracılığıyla öğrenme temelli bir ders olması ve ilkokuldan sonraki okul yıllarında da uygulanan dersle içerik olarak da alanda yarattığı algı bakımından da bütünlük oluşturması nedeniyle Talim ve Terbiye Kurulu Başkanlığının 12.09 .2018 tarihli ve 123 sayılı kararıyla dersin adı beden eğitimi ve oyun şeklinde değiştirilmiştir (Milli Eğitim Bakanlığı [MEB], 2018).

Türkiye'de beden eğitimi ve oyun dersinin işlenişinde ilkokullarda sorumlu bireyler, sınıf öğretmenleridir. Her öğrencinin ilkokul yıllarında beden eğitimi derslerinde sergileyeceği başarıda, öğretmenlerin katkısı yadsınamaz (Pehlivan vd., 2005). Dersin hedeflerine erişebilmesi için dersin uygulayıcısı olan öğretmenlerin derse yönelik tutumları ile birlikte davranışları oldukça etkilidir. Cüceloğlu ve Erdoğan (2013), eğitimin başlatıcısı, geliştiricisi ve uygulayıcısı olan öğretmeni, eğitimin 
en asli ögesi olarak tanımlamıştır. Öğretmen, öğrenciyle birlikte eğitimin öznesi konumundadır. Dolayısıyla etkin bir beden eğitimi ve oyun dersi işlenişi için bilgi, beceri, donanım açısından yetkin; sahip olduğu imkânları kullanma potansiyeli yüksek, dersin önemini ve gerekliliğini içselleştirmiş öğretmenlere ihtiyaç duyulacağı muhakkaktır. Beden eğitimi ve oyun dersinin yanında diğer derslerin de yürütülmesi sorumluluğunu taşıyan sınıf öğretmenlerinin taşıması gereken önemli nitelikler bulunmaktadır (Arslan ve Altay, 2009). Sönmez ve Cemaloğlu (2017), öğretmenlerin yüksek düzeyde mesleki bilgi ile birlikte olumlu tutum ve becerilerle donanmış olması gerektiğini belirtmişlerdir. Eğitme-öğretme gibi öğretmenlik meslek bilgisine sahip olmasının yanında, özel alan bilgisi ve genel kültür bilgisi de öğretmenlik mesleğinin gereklerindendir. Bunun yanı sıra öğretmen; dersi planlayan, derse uygun materyal geliştirebilen, öğrenciyi tanıyan, sınıf yönetimi becerisi yüksek, öğrencilerin gelişim düzeylerine uygun şekilde rehberlik edebilen, dersteki başarıyı ölçme ve değerlendirme konusunda yetkin, temel becerileri geliştirebilen, özel eğitime ihtiyacı olan bireylere bireyselleştirilmiş eğitim planı uygulayabilen kişidir. Yetişkin eğitimi konusunda öncü, ders dışı faaliyetlerde bulunabilen, kendisiyle birlikte okulu geliştirebilen öğretmenin aynı zamanda alanın içeriğine uygun sorular sorabilen, düşüncelere farklı açılardan bakabilen öğrenciler yetiştirmesiyle birlikte bilgi üretmeye özendirecek programları kullanarak model olan, disiplinler arası öğretim tecrübeleri yaratan ve alana ilişkin sorunları tanıyı uygun çözüm yolları üreterek uygulamaya koyabilen yeterlikte olması beklenmektedir (Öğretmen Yetiştirme Genel Müdürlüğü [ÖYGM], 2017).

Öğrenciye kazandırılmak istenen nitelikler beden eğitimi ve oyun dersinin etkili planlanması ile mümkündür (Çoban, Karakaya ve Coşkuner, 2010). Millî eğitim programlarının vazgeçilemez bir parçası beden eğitimi ve oyun dersinin etkin olarak işlenişinde ise öğretmenin donanımının yanında farklı değişkenler rol almaktadır. Öğretmenlerin cinsiyeti, yaşı, düzenli olarak spor yapıp yapmamaları, görev yaptıkları okulda spor tesisi ve ekipmanlarının bulunup bulunmama durumları ve daha önce (ya da hâlihazırda) aktif lisanslı spor yapıp yapmamasının öğretmenin derse karşı tutumunu ve dolayısıyla dersin verimliliğini etkilediği düşünülmektedir. Bu doğrultuda bireyin çok yönlü gelişiminde önemli bir rolü olan beden eğitimi ve oyun dersine yönelik çocuğun karşılaşttı̆g ilk öğretmenlerden biri olan sınıf öğretmenlerinin tutumları bu araştırma kapsamında incelenmiştir.

\section{Yöntem}

Araştırma, tarama modelinde betimsel niteliktedir. Tarama araştırması, deneysel araştırma gibi pozitivist sosyal bilimler içinde gelişen, örneklemden elde ettiği bilgilere dayanarak evren hakkında genelleme yapabilen araştırma modelidir (Metin, 2015). Bu araştırma, 2019-2020 eğitim ve öğretim yılı içerisinde Sivas İl Millî Eğitim Müdürlüğüne bağlı devlet ilkokullarında yapılmıştır. 


\section{Araştırmanın Evren ve Örneklemi}

Araştırmanın evrenini, Sivas İl Millî Eğitim Müdürlüğü bünyesine bağlı olarak merkez ilçe ve merkez ilçeye bağlı köylerde görev yapan sınıf öğretmenleri oluşturmaktadır. Bu kapsamda Sivas İl Millî Eğitim Müdürlüğü bünyesinde merkez ilçe ve merkez ilçeye bağlı köylerde görev yapan toplam 898 sınıf öğretmeni (MEB, 2018) araştırmanın evrenini oluşturmaktadır. Araştırmada kullanılan örneklem, kolayda örneklem yöntemiyle belirlenen toplam 328 kişiden oluşmaktadır. Kolayda örnekleme, ana kütle içerisinden seçilecek örnek kesimin araştırmacının yargılarınca belirlendiği tesadüfi olmayan örnekleme yöntemidir. Kolayda örnekleme yöntemi verilerin, ana kütleden en kolay, hızlı ve ekonomik şekilde toplandığı yöntemdir (Aaker, Kumar ve Day, 2007; Malhotra, 2004). 1000 kişilik bir evrende \pm 0,05 örneklem hatasına örneklem frekansının en az $(p=0,05, q=0,05) 278$ kişi ve üzeri olması öngörülmektedir (Yazıcıŏlu ve Erdoğan, 2004).

\section{Veri Toplama Araçları}

Araştırmada katılımcıların demografik özelliklerini belirlemek amacıyla 5 maddelik "Kişisel Bilgi Formu"; Hazar ve Tekkurşun-Demir (2018) tarafından geliştirilen 17 maddelik, üç alt boyutlu "Oyun ve Fiziksel Etkinlikler Dersine Yönelik Tutum Ölçeği" kullanılmıştır.

\section{Kişisel Bilgi Formu:}

Araştırmada katılımcıların demografik özelliklerini belirlemek için araştırmacı tarafından geliştirilen 5 maddelik kişisel bilgi formu kullanılmıştır. Kişisel bilgi formunda katılımcıların; cinsiyetleri, yaşları, düzenli spor yapıp yapmadıkları, görev yaptıkları okulda spor tesisi ve ekipmanı bulunup bulunmadığı ve daha önce (ya da hâlihazırda) aktif lisanslı spor yapıp yapmadıkları hakkında bilgi edinilmiştir.

\section{Beden Eğitimi ve Oyun Dersine Yönelik Tutum Ölçeği (BEOYT):}

Hazar ve Tekkurşun-Demir (2018) tarafından geliştirilen ölçek, 17 maddeden oluşmuştur. Ölçeklerde bulunan ifadelerin yanıtları için eşit aralıklı olduğu varsayılan beş aralıklı Likert tipi derecelendirme ("1=Kesinlikle katılmıyorum.”... “5=Kesinlikle katılıyorum.”) kullanılmıştır. Ölçek üç faktörden oluşmaktadır: 1. faktörde katılımcıların beden eğitimi ve oyun dersine ilişkin bilişsel tutumları, 2. faktörde beden eğitimi ve oyun dersine yönelik davranışsal tutumları, 3. faktörde ise beden eğitimi ve oyun dersine yönelik duygusal tutumları ölçülmektedir. Çalışmada kullanılan BEOYT ölçeğinin Cronbach Alfa iç tutarlık güvenirlik katsayısının 0,82 olduğu görülmüştür. Öyle ki ölçek çalışmada kullanılabilir bir ölçme aracı olarak kabul edilmiştir. Tezbaşaran'a (2008) göre, bir ölçme aracı 0 ile 1 arasında değer almaktadır. Bu değerlerin referans aralıklarında ise bir ölçme aracında elde edilen değerin 1'e yakın olduğu görüldüğü durumda kullanılan ölçme aracının hem maddelerinin kendi içlerinde tutarlı olduğu hem de o ölçeğin güvenilir bir ölçme aracı olduğu kabul edilmektedir (Tezbaşaran, 2008). 
Ölçeğin puanlaması ortalama ve standart sapma değerler dikkate alınarak yapılmıştır.

Beden Eğitimi ve Oyun Dersine Yönelik Tutum Ölçeği'nin (BEOYT) geliştirme aşamasına bakıldığında örneklem grubu olarak "sınıf öğretmeni adayları" alınmıştır. Ancak bu çalışmada örneklem grubu olarak “Millî Eğitim Bakanlığı bünyesinde görev yapan sınıf öğretmenleri” alınmıştır. Örneklem grubu farklılık gösterdiği için kullanılan ölçme aracının Doğrulayıcı Faktör Analizi (DFA) yapılmasının önemli olduğu görülmektedir. Yapılan DFA ile “Beden Eğitimi ve Oyun Dersine Yönelik Tutum Ölçeği'nin (BEOYT)" Millî Eğitim Bakanlığı bünyesinde görev yapan sınıf öğretmenleri için doğrulanmış bir ölçme aracı olduğu görülmüştür (Şekil 1; Tablo 1).

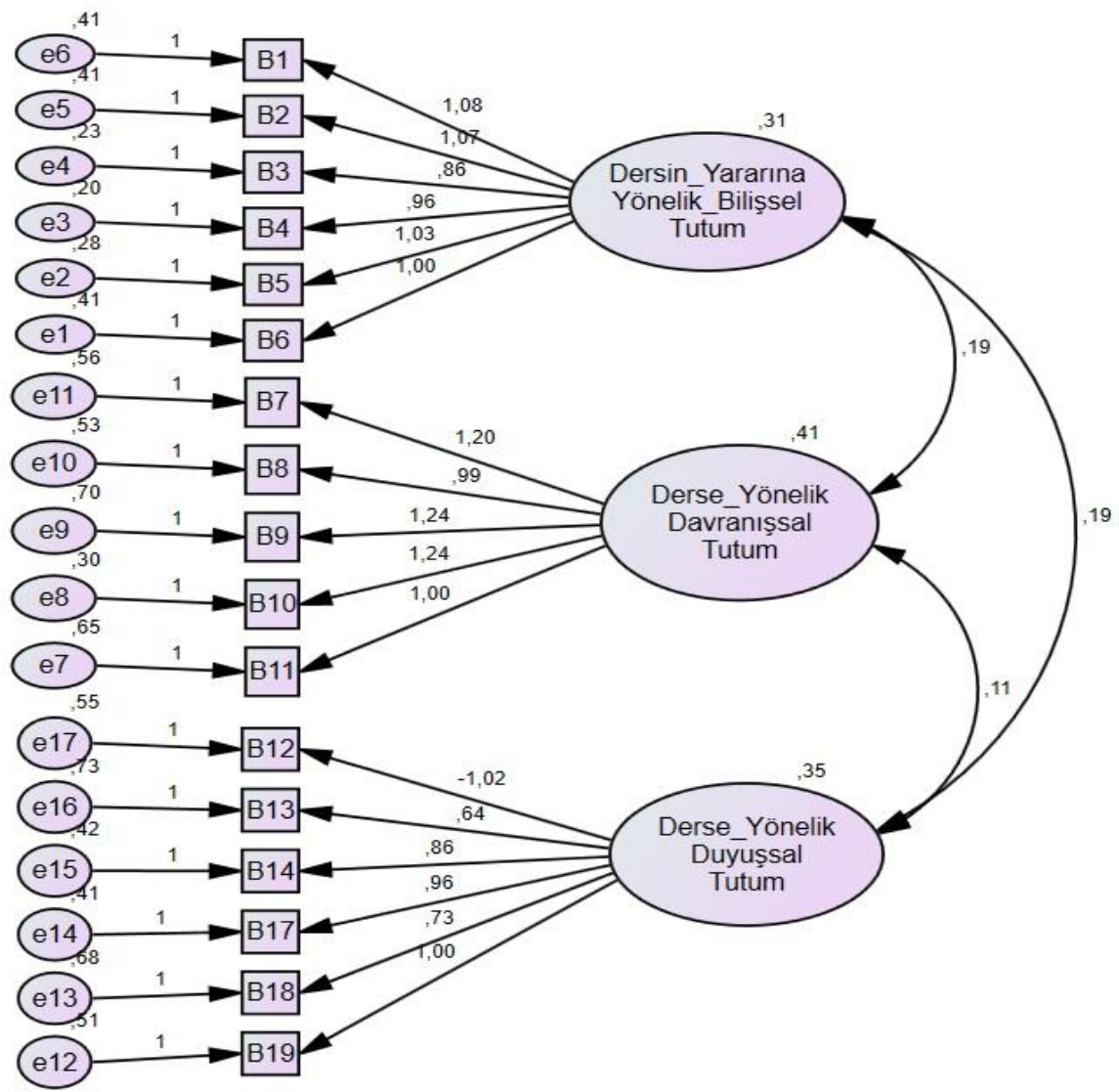

Şekil 1. AMOS Path Diyagramı

Tablo 1. Beden Eğitimi ve Oyun Dersine Yönelik Tutum Ölçeği'nin Uyum İndeksleri

\begin{tabular}{|c|c|c|c|}
\hline Model Uyum Kriteri & İyi Uуит & Kabul Edilebilir Uyum & Bulunan Değer \\
\hline CMIN/SD & $\chi^{2} / s d \leq 3$ & $\chi^{2} / \mathrm{sd} \leq 5$ & 2,683 \\
\hline \multicolumn{4}{|c|}{ Karşılaştırmalı Uyum İndeksleri } \\
\hline TLI (NNFI) & $0,95 \leq \mathrm{NNFI}$ & $0,90 \leq \mathrm{NNFI}$ & ,904 \\
\hline IFI & $0,95 \leq \mathrm{IFI}$ & $0,90 \leq \mathrm{IFI}$ & ,901 \\
\hline CFI & $0,97 \leq \mathrm{CFI}$ & $0,95 \leq \mathrm{CFI}$ & ,900 \\
\hline RMSEA & RMSEA $\leq 0,05$ & RMSEA $\leq 0,08$ & ,072 \\
\hline \multicolumn{4}{|c|}{ Artık Temelli Uyum İndeksleri } \\
\hline RMR & $0<\mathrm{RMR} \leq 0,05$ & $0<\mathrm{RMR} \leq 0,08$ & ,061 \\
\hline \multicolumn{4}{|c|}{ Mutlak Uyum İndeksleri } \\
\hline GFI & $0,90 \leq \mathrm{GFI}$ & $0,85 \leq \mathrm{GFI}$ & 899 \\
\hline AGFI & $0,90 \leq \mathrm{AGFI}$ & $0,85 \leq \mathrm{AGFI}$ & ,867 \\
\hline
\end{tabular}




\section{Verilerin Toplanması}

Veri elde etmek için kullanılan ölçekler, 2019-2020 eğitim ve öğretim yılı içerisinde Sivas ìl Millı̂ Eğitim Müdürlüğü bünyesinde merkez ilçe ve merkez ilçeye bağlı köylerde görev yapan toplam 328 sınıf öğretmenine gönüllülük esasına dayanılarak farklı zamanlarda yüz yüze uygulanmıştır.

\section{Verilerin Analizi}

Araştırmanın analizinde IBM SPSS 25 Paket programı kullanılarak değişkenler yüzde (\%), frekans, ortalama değerler açısından tanımlayıcı istatistikleri yapılmıştır. Diğer taraftan değişkenlerin normal dağılım gösterip göstermediklerini tespit etmek amacıyla verilerin çarpıklık ve basıklık değerlerine bakılmış olup en düşük Skewness değerinin -1,050 olduğu en yüksek Kurtosis 1,591 değerlerinin olduğu görülmüştür. Buradan hareketle değişkenler arasındaki farklılıkları belirlemek amacıyla ikili karşılaştırmalarda bağımsız gruplar $t$ testi ve üç ve üzeri değişkenlerin karşılaştırılmasında tek yönlü varyans analizi (ANOVA) testlerinden faydalanılmıştır. Üç ve üzeri değişken arasında farkın tespit edildiği durumlarda değişkenlerin homojenliği Levene Testi ile belirlenmiştir. Homojen dağılım gösteren verilerin karşılaştırılmasında Tukey Testi'nden yararlanılmıştır.

\section{Bulgular}

Sınıf öğretmenlerinin beden eğitimi ve oyun dersine yönelik tutum ve görüşlerini analiz etmek amacıyla yapılan bu çalışmada, araştırmaya katılan sınıf öğretmenlerinin düzenli olarak (haftada en az 3 gün) spor yapma durumlarına, görev yaptıkları okulda spor tesisi ve ekipman (saha, salon, malzeme vb.) bulunması durumuna ve daha önce ya da hâlihazırda aktif lisanslı olarak spor yapma durumlarına göre elde edilen bulgular bu bölümde ele alınmıştır.

Tablo 2. Araştırmaya Katılan Sınıf Öğretmenlerinin Kişisel Bilgilerinin Dağılımı

\begin{tabular}{llcc}
\hline Kişisel Bilgiler & Nitelikler & $f$ & $\mathbf{( \% )}$ \\
\hline \multirow{2}{*}{ Cinsiyet } & Kadın & 136 & 41,5 \\
& Erkek & 192 & 58,5 \\
\hline \multirow{2}{*}{ Yaş } & $20-30$ Yaş & 26 & 7,9 \\
& $31-40$ Yaş & 91 & 27,7 \\
\multirow{2}{*}{ Haftada En Az Üç Kez Düzenli Spor Yapma Durumu } & 41 Yaş ve Üzeri & 211 & 64,3 \\
\hline Görev Yaptıkları Okulda Spor Tesisi ve Ekipmanı (Saha, & Evet & 54 & 16,5 \\
Salon, Malzeme vb.) Mevcut Olması Durumu & Hayır & 274 & 83,5 \\
\hline Daha Önce (Ya da Hâlihazırda) Aktif Lisanslı Olarak & Hayır & 108 & 32,9 \\
Spor Yapma Durumu & Hayır & 220 & 67,1 \\
\hline & Toplam & 50 & 15,2 \\
& & 278 & 84,8 \\
\hline
\end{tabular}

Tablo 2'de araştırmaya katılan sınıf öğretmenlerinin kişisel bilgilerinin dağılımı verilmiştir. Buna göre araştırmaya katılan sınıf öğretmenlerinin 136'sı (\%41,5) kadın, 192'si (\%58,5) erkek öğretmendir. Yine öğretmenlerin büyük bir çoğunluğunun 41 yaş ve üzerinde $(211, \% 64,3)$ olduğu belirlenmiştir. Sınıf öğretmenlerinin çok büyük bir kısmının düzenli olarak spor yapmadığı (274, 
\%83,5) ve daha öncesinde ya da hali hazırda lisanslı olarak herhangi bir spor branşı ile uğraşmadıkları $(278, \% 84,8)$ belirlenmiştir. Bununla birlikte sınıf öğretmenlerinin görev yaptıkları okullarda spor salonu ve ekipmanı gibi olanaklarının az olduğu belirlenmiştir $(108, \% 32,9)$.

Tablo 3. Araştırmaya Katılan Sınıf Öğretmenlerinin Düzenli Spor Yapma Durumlarına Göre Beden Ĕ̆itimi ve Oyun Dersine Yönelik Tutumlarının Karşılaştırılması (Bağımsız Gruplar t Testi)

\begin{tabular}{lcccccc}
\hline Alt Boyutlar & $\begin{array}{c}\text { Düzenli Spor } \\
\text { Yapma Durumu }\end{array}$ & $f$ & $\overline{\mathbf{X}}$ & S.S. & $\boldsymbol{t}$ & $\boldsymbol{p}$ \\
\hline 1) Dersin Yararlarına İlişkin & Evet & 54 & 4,39 & 0,57 & 2,568 & $0,011^{*}$ \\
Bilişsel Tutum & Hayır & 274 & 4,16 & 0,61 & \\
\hline 2) Derse Yönelik Davranışsal & Evet & 54 & 3,67 & 0,79 & \multirow{2}{*}{2,622} & $0,009^{*}$ \\
Tutum & Hayır & 274 & 3,36 & 0,79 & & \multirow{2}{*}{0,866} \\
\hline 3) Derse Yönelik Duygusal Tutum & Evet & 54 & 4,03 & 0,48 & \multirow{2}{*}{0,168} & 0,060 \\
\hline
\end{tabular}

$\mathrm{n}=328 ;{ }^{*} p<0,05$

Tablo 3'te araştırmaya katılan öğretmenlerin düzenli olarak spor yapma durumlarına göre beden eğitimi ve oyun dersine yönelik tutumları karşılaştırılmıştır. Buna göre düzenli olarak spor yapan öğretmenlerin dersin yararlarına ilişkin bilişsel tutumlarının ve ders yönelik davranışsal tutumlarının daha yüksek ortalamaya sahip oldukları görülmüştür.

Tablo 4. Araştırmaya Katılan Sınıf Öğretmenlerinin Görev Yaptıkları Okullardaki Spor Tesisi Bulunma Durumlarına Göre Beden Eğitimi ve Oyun Dersine Yönelik Tutumlarının Karşılaştırılması (Bağımsız Gruplar t Testi)

\begin{tabular}{|c|c|c|c|c|c|c|}
\hline Alt Boyutlar & Spor Tesisi Durumu & $f$ & $\overline{\mathbf{x}}$ & S.S. & $t$ & $p$ \\
\hline \multirow{2}{*}{$\begin{array}{l}\text { 1) Dersin Yararlarına İlişsin } \\
\text { Bilişsel Tutum }\end{array}$} & Evet & 108 & 4,23 & 0,53 & 0,687 & 0,492 \\
\hline & Hayır & 220 & 4,18 & 0,64 & & \\
\hline \multirow{2}{*}{$\begin{array}{l}\text { 2) Derse Yönelik Davranışsal } \\
\text { Tutum }\end{array}$} & Evet & 108 & 3,52 & 0,76 & 1,759 & 0,080 \\
\hline & Hayır & 220 & 3,35 & 0,82 & & \\
\hline \multirow{2}{*}{ 3) Derse Yönelik Duygusal Tutum } & Evet & 108 & 4,05 & 0,40 & 0,914 & 0,072 \\
\hline & Hayır & 220 & 4,00 & 0,48 & & \\
\hline
\end{tabular}

Tablo 4'te araştırmaya katılan sınıf öğretmenlerinin göreve yaptıkları okullarda spor tesisi bulunma durumlarına göre beden eğitimi ve oyun dersine yönelik tutumları karşılaştırılmıştır. Buna göre sınıf öğretmenlerinin söz konusu değişkene göre beden eğitimi ve oyun dersine yönelik tutumlarında herhangi bir farklılığın olmadığı görülmüştür.

Tablo 5. Araştırmaya Katılan Sınıf Öğretmenlerinin Daha Önce ya da Hâlihazırda Aktif Lisanslı Olarak Spor Yapma Durumlarına Göre Beden Eğitimi ve Oyun Dersine Yönelik Tutumlarının Karşılaştırılması (Bağımsız Gruplar t Testi)

\begin{tabular}{|c|c|c|c|c|c|c|}
\hline Alt Boyutlar & $\begin{array}{c}\text { Lisansli Spor Yapma } \\
\text { Durumu }\end{array}$ & $f$ & $\overline{\mathbf{x}}$ & S.S. & $t$ & $p$ \\
\hline 1) Dersin Yararlarına & Evet & 50 & 4,49 & 0,50 & \multirow{2}{*}{3,748} & \multirow{2}{*}{$0,001^{*}$} \\
\hline İlişkin Bilişsel Tutum & Hayır & 278 & 4,14 & 0,60 & & \\
\hline 2) Derse Yönelik & Evet & 50 & 3,73 & 0,74 & \multirow{2}{*}{3,192} & \multirow{2}{*}{$0,002^{*}$} \\
\hline Davranışsal Tutum & Hayır & 278 & 3,34 & 0,79 & & \\
\hline 3) Derse Yönelik & Evet & 50 & 4,19 & 0,33 & \multirow{2}{*}{2,989} & \multirow{2}{*}{$0,003^{*}$} \\
\hline Duygusal Tutum & Hayır & 278 & 3,98 & 0,46 & & \\
\hline
\end{tabular}


Tablo 5'te araştırmaya katılan sınıf öğretmenlerinin daha öncesinden ya da hâlihazırda lisanslı olarak spor yapma durumlarına göre beden eğitimi ve oyun dersine yönelik tutumlarına bakıldığında bütün alt boyutlarda istatistiksel olarak anlamlı farklılıkların olduğu görülmektedir. Buna göre hem bilişsel hem davranışsal ve hem de duygusal boyutta lisanlı spor geçmişi olan öğretmenlerin daha yüksek ortalamaya sahip oldukları tespit edilmiştir.

\section{Tartışma}

Sınıf öğretmenlerinin beden eğitimi ve oyun dersine yönelik tutumlarının incelendiği bu araştırmaya Sivas il merkezinde yer alan ve çeşitli okullarda aktif olarak görev yapan 136'sı kadın, 192 erkek, toplamda 328 sınıf öğretmeni katılmıştır.

Araştırmaya katılan sınıf öğretmenlerinin düzenli spor yapma durumlarına göre tutum puanları ortalama değerlerine bakıldığında bilişsel tutum ile davranışsal tutum puanı arasında istatistiksel anlamlı bir farkın olduğu görülmüştür (Tablo 5). Dalaman (2015) yapmış olduğu çalışmada sınıf öğretmeni adaylarının beden eğitimi ve oyun öğretimi dersine yönelik tutum puanlarının geçmişte spor yapma durumlarına göre farklılık gösterdiğini belirtmiştir. Benzer şekilde, Öncü ve Cihan (2012) tarafından yapılmış araştırmada sınıf öğretmeni adaylarının beden eğitimi ve oyun dersine yönelik tutum puanları, spor yapma durumu değişkenine göre anlamlı bir farklılık göstermiştir. Bir başka çalışmada Güvendi ve Serin (2019), egzersiz yapan sınıf öğretmenlerinin beden eğitimi ve oyun dersine yönelik tutumlarını yüksek bulurken egzersiz yapmayan öğretmenlerin fiziksel aktivitenin önemine dair fikirleri olmadığı ve egzersize düzenli olarak ayrılan zamanı boşa harcanan zaman olarak değerlendirdikleri sonucuna ulaşmışlardır. Elde edilen sonuçlar yapılan bu araştırma ile paralellik göstermektedir. Alemdağ, Öncü ve Sakallığlu (2014), beden eğitimi dersine yönelik tutum ve öz-yeterlilikleri inceledikleri çalışmalarında düzenli bir şekilde spor yaptığını ifade eden sınıf öğretmeni adaylarının beden eğitimi ve oyun dersine yönelik tutumlarını anlamlı bir şekilde daha yüksek bulmuşlardır. Elde edilen bu bulgular, yapılan bu çalışmanın bulgularını desteklemektedir. Sonuç olarak spor yapmayı yaşamlarında davranışa dönüştüren öğretmenlerin, uygulamalı bir ders olan ve ağırlıklı olarak gösterip yaptırma öğretim yönteminin kullanıldığı beden eğitimi ve oyun dersine yönelik tutumları yüksek olmaktadır.

Sınıf öğretmenlerinin görev yaptıkları okullardaki spor tesisi bulunma durumlarına göre tutum puanları ortalama değerlerine bakıldığında istatistiksel anlamlı bir farkın olmadığı görülmüştür (Tablo 4). Pehlivan vd. (2005), yapmış olduğu çalışmada beden eğitimi ve oyun derslerinin istenilen şekilde yürütülmesini engelleyen etmenlerin başında malzeme, araç-gereç ve salon eksikliği olduğunu ifade etmişlerdir. Benzer şekilde, Tortop (2005) tarafından yapılmış çalışmada Manisa il merkezinde, beden eğitimi derslerini de yürüten sınıf öğretmenlerinin \%40’ının okulda araç-gereç bulunmayışından yakındığı ifade edilmiştir. Çıldır (2019), sınıf öğretmenlerinin 
beden eğitimi ve oyun dersine ilişkin tutumlarını incelediği çalışmasında okullarda spor salonu bulunması açısından öğretmen tutumlarının anlamlı bir şekilde farklılaşmadığı sonucuna ulaşmıştır. Elde edilen bu sonuçlar çalışmamızı destekler niteliktedir. Yapılan başka bir çalışmada ise Bozdemir, Çimen, Kaya ve Demir (2015), Tokat il genelindeki ilkokullarda beden eğitimi ve oyun derslerinin işlenişi için gerekli olan spor salonlarının yeterli olmadığını ve ihtiyacı karşılamadığını tespit etmişlerdir. Ülkemizde, genel anlamda eğitim sorunlarının başında nicelikle ilgili birtakım sorunlar gelmektedir. Bu sorunların merkezinde de okulların fiziki bakımdan yetersiz oluşu bulunmaktadır. Bilinmelidir ki nicelikle ilgili bu ve bunun gibi problemler giderilmeden eğitimde gerekli niteliği elde etmek de oldukça zordur. Bu bakımdan öncelikle okulların fiziki koşullarının düzeltilmesi, daha kaliteli eğitim alınması adına önem arz etmektedir. Tüm bunlara rağmen yapılan bu çalışmada istatistiksel olarak anlamlı bir farkın çımamasının nedeni olarak ülkemizdeki okulların fiziki şartlarını bilerek mesleği yürüten öğretmenlerin koşullara ait beklentilerini düşük tuttukları öngörülmektedir.

Sınıf öğretmenlerinin daha önce ya da hâlihazırda aktif lisanslı olarak spor yapma durumlarına göre bilişsel tutum, davranışsal tutum ve duygusal tutum puanları arasında istatistiksel anlamlı bir farkın olduğu tespit edilmiştir (Tablo 5). Öncü ve Cihan (2012) yapmış oldukları araştırmada sınıf öğretmeni adaylarının beden eğitimi ve oyun dersine yönelik tutumlarını, spor yapma durumu değişkenine göre incelemiştir. Bu araştırma sonucuna göre öğrencilerin beden eğitimi ve oyun dersine yönelik tutumları ile spor yapma durumu değişkenleri arasında anlamlı bir farklılık tespit edilmiştir $(\mathrm{p}<0,05)$. Spor yapanların spor yapmayan öğrencilere göre tutum puanlarının daha yüksek olduğunu ifade etmişlerdir. Alemdağ vd. (2014) tarafından gerçekleştirilen çalışmada da düzenli olarak spor yaptığını belirten sını öğretmenlerinin beden eğitimi dersine yönelik tutumları anlamlı bir şekilde daha yüksek bulunmuştur. Benzer şekilde Güvendi ve Serin (2019), spor geçmişi olan öğretmenlerin spor yapmamış öğretmenlere göre fiziksel aktiviteye katılmaya daha fazla motive oldukları ve daha önce sporla hiç uğraşmamış öğretmenlerin fiziksel aktivite ile ilgili yeterli bilgiye sahip olamadıkları sonucuna ulaşmışlardır. Alanda yapılan bir başka çalışmada Tortop (2005), Afyon ilinde sınıf öğretmenlerinin eğitsel oyun uygulamalarına yönelik yapmış olduğu çalışmasında mesleğe başlamadan önce ya da sonra lisanslı olarak spor yapanların oranını \%22,5 olarak belirlemiştir. \%77,5 oranında sınıf öğretmeninin lisanslı olarak spor yapmadığı tespit edilmiştir.

Elde edilen bulgular, yapılan bu çalışmanın bulgularını destekler niteliktedir. Daha önce ya da hâlihazırda aktif lisanslı olarak spor yapmama durumlarının, sınıf öğretmenlerinin beden eğitimi dersine olan duygusal ve davranışsal tutumlarını olumsuz etkilediği ortadadır. Bu nedenledir ki sınıf öğretmenlerinin, fiziksel aktivitenin önemini içselleştiremedikleri ve beden eğitimi ve oyun dersini, diğer derslerin müfredatını tamamlamaya yönelik elverişli boşluk olarak değerlendirdikleri 
düşünülmektedir. Eğitimde rol model olan öğretmenlerin bu tutumunun, öğrencilerin spora yönelip lisanslı sporcu olarak yaşamlarını sürdürmeleri ihtimalini de olumsuz etkilediği düşünülmektedir. Yapılan araştırmalar ülkemizdeki lisanslı sporcu sayısının gelişmiş ülkelere oranla oldukça düşük olduğunu ortaya koymaktadır.

\section{Sonuç}

Araştırmaya 136'sı kadın, 192'si erkek olmak üzere toplam 328 öğretmen katılmıştır. Buradan hareketle, Sivas merkezde görev yapan sınıf öğretmenlerinin büyük bir çoğunluğunun erkek olduğu söylenebilir.

Öğretmenlerin düzenli olarak spor yapma durumları incelendiği zaman 328 öğretmenden 274 'ünün $(\% 83,5)$ düzenli olarak spor yapmadıkları ortaya çıkmıştır. Bu durumun sınıf öğretmenlerinin beden eğitimi ve oyun dersine yönelik bilişsel ve davranışsal tutumlarını da olumsuz etkilediği görülmüştür.

Sınıf öğretmenlerinin \%67,1'inin görev yaptıkları okulda spor tesisi (saha, salon vb.) bulunmamaktadır. Tesis yetersizliğinin beden eğitimi ve oyun dersinin işlenişindeki verimliliği olumsuz etkilediği düşünülmektedir. Okullarda spor salonlarının olmaması, bu dersin işlenebilmesi için güvenli bir ortamın ve materyallerin olmaması öğretmenlerin bu derse olan tutumlarında olumsuz etkiye neden olmaktadır.

Sınıf öğretmenlerinin daha önce (ya da hâlihazırda) aktif lisanslı olarak spor yapma durumlarına bakıldığında, \%84,8 gibi büyük bir kısmının yaşamlarında aktif lisanslı olarak spor yapmadıkları görülmüştür. Bununla birlikte \%7,6'sının lisanslı futbol, \%2,4'ünün ise lisanslı voleybol sporcusu olduğu sonucuna ulaşılmıştır. Sonuç olarak, yaşamında sporla hiçbir bağı olmayan sınıf öğretmenlerinin beden eğitimi ve oyun dersine yönelik bilişsel, duygusal ve davranışsal tutumlarının, aktif lisanslı olarak spor yapan öğretmenlere göre net bir ifadeyle daha düşük olduğu tespit edilmiştir.

Bu doğrultuda yapılan bu araştırma soncunda aşağıdaki öneriler sunulmaktadır.

1. Üniversitelerin "sınıf öğretmeni" yetiştiren bölümlerinde okutulan "beden eğitimi öğretimi" dersinin içerik ve işleniş bakımından daha etkin hale getirilerek öğretmen adaylarının beden eğitimi dersine karşı "olumlu bilişsel tutum" geliştirmeleri ve “Öğretmenlik Uygulamaları" dersleriyle de "olumlu duygusal ve davranışsal tutumun sağlanması önerilmektedir.

2. Mevcut okulların tesis/salon, araç gereç ve malzeme bakımından eksikliklerinin giderilmesinin ve yapılması planlanan yeni okul binalarının bünyesine spor salonu/sahası eklenmesinin dersin işlenişini verimli kılacağı düşünülmektedir. 
3. İlkokullarda sporcu alt yapısı oluşturmak, millî eğitimin temel politikalarından biri haline getirilebilir. Sınıf mevcutları da beden eğitimi ve oyun dersinin verimli işlenişine uygun şekilde planlanabilir.

4. Sınıf öğretmeni adayları akademik eğitimleri süresince ya da mesleklerinin ilk yıllarında "aktif lisanslı olarak spor yapmaya" teşvik edilebilir. Bu durum sağlanamadığı takdirde, sınıf öğretmenlerinin eğlence amaçlı spor yapmaları sağlanabilir.

5. Özel yetenek ve ilgi gerektiren beden eğitimi derslerine, özel okullarda olduğu gibi devlet okullarında da "beden eğitimi mezunu” öğretmenlerin girmesi, dersin işlenişini daha verimli kılabilir. Bununla birlikte, özel okullarda görev yapan sınıf öğretmenleri için de ayrı bir çalışma yapılabilir.

6. Beden eğitimi dersinin diğer derslere ait eksikliklerin giderildiği bir alan olma algısının giderilmesi sağlanabilir.

\section{Kaynaklar}

Aaker, D. A., Kumar, V. \& Day, G. S. (2007). Marketing research (9. b.). Danvers: John Wiley \& Sons.

Alemdağ, S., Öncü, E. \& Sakallığlu, F. (2014). Sınıf öğretmeni adaylarının beden eğitimi dersine yönelik tutum ve öz-yeterlikleri. Abant İzzet Baysal Üniversitesi Ĕ̆itim Fakültesi Dergisi, 14(2), $45-60$.

Arslan, Y. \& Altay, F. (2009). Sınıf öğretmenlerinin beden eğitimi dersine ilişkin görüşlerinin bazı eğilimleri açısından incelenmesi. Selçuk Üniversitesi Beden Eğitimi ve Spor Bilim Dergisi, 11(1), 14-23.

Bozdemir, R., Çimen, Z., Kaya, M. \& Demir, O. (2015). Sınıf öğretmenlerinin beden eğitimi ve spor dersinde karşılaştıkları problemler (Tokat ili örneği). Uluslararası Türk Ĕ̆itim Bilimleri Dergisi, 2015(5), 221-234.

Cüceloğlu, D. \& Erdoğan, İ. (2013). Öğretmen olmak. İstanbul: Final Kültür Sanat Yayınları.

Çıldır, A. (2019). Sını öğretmenlerinin beden eğitimi ve oyun dersine ilişkin tutumlarının incelenmesi. (Yüksek Lisans Tezi). http://tez.yok.gov.tr sayfasından erişilmiştir.

Çoban, B., Karakaya, Y. E. \& Coşkuner, Z. (2010). İlköğretimde beden eğitimi dersinde kullanılan öğretmen kılavuz kitaplarının sınıf öğretmenlerinin görüşlerine göre değerlendirilmesi. 9. Ulusal Sını Öğretmenliği Ĕ̆itimi Sempozyumu içinde (s. 20-22).

Dalaman, O. (2015). Sınıf öğretmeni adaylarının "beden eğitimi ve oyun öğretimi” dersine yönelik tutumlarının değişik faktörlerce incelenmesi. Mehmet Akif Ersoy Üniversitesi Ĕ̆gitim Fakültesi Dergisi, 36, 59-71. 
DeCorby, K., Halas, J., Dixon, S., Wintrup, L. \& Janzen, H. (2005). Classroom teachers and the challenges of delivering quality physical education. The Journal of Educational Research, 98(4), 208-221.

Güvendi, B. \& Serin, H. (2019). Sınıf öğretmenliği adaylarının oyun ve fiziksel etkinlikler dersine yönelik tutumları ile fiziksel aktiviteye katılım motivasyonlarının incelenmesi. Elektronik Sosyal Bilimler Dergisi, 18(72), 1957-1968.

Hazar, Z. \& Tekkurşun-Demir, G. (2018). Sınıf öğretmeni adaylarının oyun ve fiziksel etkinlikler dersine yönelik tutum ölçeği: geçerlik ve güvenirlik çalışması. Journal of Human Sciences, 15(2), 1206-1215.

Karakoç, İ. \& Sezer, A. (2007). İlköğretim II. Kademe sosyal bilgiler dersi coğrafya konularının öğretiminde çoklu zeka uygulamalarının akademik başarıya etkisi. Türkiye Sosyal Araştırmaları Dergisi, 2, 9-20.

Kuru, E. (2003). Farklı statüdeki beden eğitimi bölümü öğrencilerinin kişilik özellikleri. Gazi Üniversitesi Gazi Ĕ̆itim Fakültesi Dergisi, 23(1), 175-191.

Malhotra, N. K. (2004). Marketing research an applied orientation (4. b.). New Jersey: Pearson Prentice Hall.

MEB. (2018). İlköğretim kurumları (ilkokul ve ortaokul) haftalık ders çizelgesi. Ankara: Millî Eğitim Bakanlı̆̆ı Tebliğgler Dergisi.

Metin, M. (Ed.). (2015). Kuramdan uygulamaya eğitimde bilimsel araştırma yöntemleri. Ankara: Pegem Akademi Yayınları.

Öncü, E. \& Cihan, H. (2012). Sınıf öğretmeni adayları için beden eğitimi dersi tutum ölçeğinin geliştirilmesi. Dicle Üniversitesi Ziya Gökalp Eğitim Fakültesi Dergisi, 18, 31-47.

ÖYGM. (2017). Öğretmenlik uygulaması yönergesi. https://oygm.meb.gov.tr/www/iletisim/icerik/277 sayfasından erişilmiştir.

Pehlivan, Z., Dönmez, B. \& Yaşat, H. (2005). Sınıf öğretmenlerinin beden eğitimi dersine yönelik görüşleri. Gazi Beden Ĕ̆itimi ve Spor Bilimleri Dergisi, 10(3), 51-62.

Sönmez E. \& Cemaloğlu, N. (2017). İlköğretim okulu öğretmenlerinin mesleki imaj algısı ile örgütsel vatandaşlık davranışları arasındaki ilişki. Abant İzet Baysal Üniversitesi Eğitim Fakültesi Dergisi, 17(4), 2117-2141.

Tezbaşaran, A. A. (2008). Likert tipi ölçek geliştirme kılavuzu. Ankara: Türk Psikologları Derneği.

Tortop, Y. (2005). Sınıf öğretmenlerinin beden eğitimi dersi ve eğitsel oyun uygulamaları. (Yüksek Lisans Tezi). http://tez.yok.gov.tr sayfasından erişilmiştir.

Yazıcıoğlu, Y. \& Erdoğan, S. (2004). SPSS uygulamalı bilimsel araştırma yöntemleri. Ankara: Detay. 


\section{Extended Summary}

In Turkey, primary school teachers are responsible for physical education and game lessons. The contribution of teachers to the success of each student in physical education classes during primary school years is undeniable (Pehlivan et al., 2005). In order for the course to reach its goals, the attitudes and behaviours of the teachers, who are the implementers of the course, are very effective. Cüceloğlu and Erdoğan (2013) defined the teacher, who is the initiator, developer, and implementer of education, as the most essential element of education. The teacher is the subject of education together with the student. Therefore, they are competent in terms of knowledge, skills, and equipment for an effective physical education and game lesson. Classroom teachers, who are responsible for conducting other lessons besides physical education and game lessons, have important qualifications (Arslan and Altay, 2009). Sonmez and Cemaloğlu (2017) stated that teachers should be equipped with positive attitudes and skills along with a high level of professional knowledge.

In addition to having teaching profession knowledge such as teaching-teaching, specific field knowledge, and general cultural knowledge are also among the requirements of the teaching profession. In addition, the teacher is a person who plans the lesson, develops materials suitable for the lesson, knows the student, has high classroom management skills, guides students in accordance with their development level, is competent in measuring and evaluating the success in the lesson, develops basic skills, and applies an individualized education plan to individuals in need of special education.

The teacher, who is a pioneer in adult education, can engage in extracurricular activities, develop the school together with himself, raise students who can ask questions in accordance with the content of the field, look at ideas from different angles, be a model by using programs that encourage knowledge production, create interdisciplinary teaching experiences, and recognize problems related to the field. It is expected that they will be able to solve and implement the appropriate ways (ÖYGM, 2017).

Qualifications desired to be gained by the student are possible with the effective planning of physical education and game lessons (Çoban et al., 2010). In addition to the equipment of the teacher, different variables play a role in the effective teaching of physical education and game lessons, which are an indispensable part of national education programs. It is thought that teachers' gender, age, whether they do sports regularly, whether there is a sports facility and equipment in the school they work in, and whether they have done (or currently) actively licensed sports affect the teacher's attitude towards the lesson and therefore the efficiency of the lesson. In this direction, the attitudes of classroom teachers, who are one of the first teachers that the child encounters, towards physical 
education and game lessons, which have an important role in the multi-faceted development of the individual, were examined within the scope of this research.

The research is descriptive in the scanning model. This research was carried out in public primary schools affiliated to Sivas Provincial Directorate of National Education in the 2019-2020 academic year. The sample used in the study consists of a total of 328 people determined by the convenience sampling method.

In order to determine the demographic characteristics of the participants in the research, a 5item "Personal Information Form" and a 17-items, three-dimensional "Attitude Scale Towards Play and Physical Activities Lesson" developed by Hazar and Tekkurşun-Demir (2018) were used. In the analysis of the research, descriptive statistics were made in terms of percentage (\%), frequency, and mean values by using IBM SPSS 25 Package program.

A total of 328 teachers, 136 women and 192 men, participated in the study. From this point of view, it can be said that the majority of the classroom teachers working in the centre of Sivas are male. When the regular sports status of the teachers was examined, it was found that 274 (83.5\%) out of 328 teachers did not do sports regularly. It was observed that this situation negatively affected the cognitive and behavioural attitudes of classroom teachers towards physical education and game lessons. There is no sports facility (field, hall, etc.) in the school where $67.1 \%$ of the classroom teachers work. It is thought that the lack of facilities negatively affects the efficiency of physical education and game lessons.

The absence of gymnasiums in schools, the absence of a safe environment and materials for this course cause a negative impact on teachers' attitudes towards this course. Considering the previous (or current) active sports status of the classroom teachers, it was seen that $84.8 \%$ of them did not do sports actively licensed in their lives. However, it was concluded that $7.6 \%$ of them were licensed football players, and $2.4 \%$ were licensed volleyball players.

As a result, it has been determined that the cognitive, emotional, and behavioural attitudes of the classroom teachers, who have no connection with sports in their lives, towards physical education and game lessons, are clearly lower than the teachers who play sports as actively licensed. From this point of view, it is recommended that classroom teachers do regular sports activities and that the necessary sports equipment and physical areas are not sufficient in the schools where they work. On this way educational content that trains "Classroom Teacher" can be made more effective in terms of teaching and teaching. 


\section{Araştırmacıların Katkı Oranı Beyanı}

$\mathrm{Bu}$ araştırmaya, birinci yazar \%60 oranında, ikinci yazar \%40 oranında katkı sağlamıştır.

\section{Destek ve Teşekkür Beyanı}

Bu çalışmanın yazım sürecinde katkı ve desteklerinden ötürü doktora öğrencisi Oğuzhan Gül'e teşekkür ederiz.

\section{Çatışma Beyanı}

Araştırmacıların araştırma ile ilgili diğer kişi ve kurumlarla herhangi bir kişisel ve finansal çıkar çatışması yoktur.

\section{Etik Kurul Beyanı}

Bu araştırma, Sivas Cumhuriyet Üniversitesi Etik Kurulunun 31.10.2019 tarihli ve 60263016050.06.04-E.416800 sayılı kararı ile yürütülmüştür. 